\title{
ANALISIS GANGGUAN TRANSMISI PADA SISTEM KOMUNIKASI KABEL LAUT MATRIX CABLE SYSTEM
}

\author{
Yoggi Prasetyo Octavian \\ Program Studi Informatika, Universitas Indraprasta PGRI \\ yoggip.octavian@gmail.com
}

\begin{abstract}
Abstrak
Saat ini teknologi transmisi komunikasi jarak jauh berkembang dengan cepat yang didorong oleh meningkatnya kebutuhan manusia ditinjau dari kualitas transmisi maupun kuantitas pelayanan. Untuk mendukung komunikasi jarak jauh yang menghubungkan antar pulau dan negara, saat ini berkembang sistem transmisi fiber optik yang mempunyai kelebihan dibandingkan dengan sistem transmisi yang lain seperti rugi-rugi transmisi yang rendah, ukuran lebih kecil dan ringan, tahan terhadap interferensi elektromagnetik dan interferensi frekuensi radio sehingga bebas dari crosstalk. Salah satu sistem transmisi fiber optik antar negara yang sedang berkembang adalah sistem komunikasi kabel laut Matrix Cable System (MCS) yang menghubungkan Jakarta dengan Singapura. Pada penelitian ini akan membahas mengenai gangguan transmisi pada sistem komunikasi kabel laut Matrix Cable System Jakarta - Singapura. Untuk mengetahui penyebab gangguan diperlukakan proses analisa mulai dari pendeteksian gangguan, restorasi trafik ke jalur lain supaya trafik tetap berjalan, pendeteksian lokasi/titik kerusakan, sampai melakukan perbaikan dengan penyambungan kabel fiber optik yang terputus, dan melakukan pengukuran hasil perbaikan. Setelah proses analisa dilakukan diketahui bahwa belum adanya jalur backup permanen sehingga butuh waktu untuk restorasi trafik, proses perbaikan yang cukup lama karena proses perizinan dan hasil pengukuran redaman (splice loss) kabel fiber optik hasil sambungan sudah memenuhi standar yaitu 0.0 - $0.3 \mathrm{~dB}$.
\end{abstract}

Kata Kunci: kabel laut, fiber optik, Matrix Cable System, fiber cut

\begin{abstract}
Today long distance transmission technology is developing rapidly which is driven by the increasing human needs viewed from transmission quality and quantity of service. To support long haul transmission links between islands and countries, currently growing an optical fiber transmission has advantages compared with other transmission such as transmission losses are better, smaller size and lighter, resistant from electromagnetic and radio frequency interference, free from crosstalk. One optical fiber transmission is a submarine cable communications system of Matrix Cable System (MCS) which connects Jakarta to Singapore. This research will analysis the transmission of the submarine cable communication system Matrix Cable System Jakarta - Singapore has happened. To find out the cause of the disturbance, the analysis process starts from the detection of disturbances, restoring traffic to other link, fixed detection, location detection / point of damage, to making repairs with disconnected fiber optic cable connectors, and measuring the repair results. After analysis is done, it does not have a permanent backup line, it takes time for traffic restoration, the repair process is quite long because the licensing process and the results of measurement attenuation (splice loss) optical fiber cable connection results are in accordance with the standard, $0.0-0.3 \mathrm{~dB}$.
\end{abstract}

Keywords: submarine cable, fiber optik, Matrix Cable System, fiber cut

\section{PENDAHULUAN}

Sistem komunikasi kabel laut untuk saat ini di Indonesia hanya ada 6 provider telekomunikasi yang mendukung transmisi jarak jauh antar negara (Indonesia Singapura) yaitu Telkom, Indosat, XL, Moratel, Matrix Network dan Pgascom. Sehingga untuk akses informasi mengenai operasional sistem komunikasi kabel laut masih terbatas. Oleh karena itu, pada penelitian ini akan membahas mengenai analisa gangguan transmisi pada sistem komunikasi kabel laut Matrix Cable System (MCS) yang menghubungkan Jakarta dengan Singapura. Dengan adanya pembahasan mengenai sistem komunikasi 
kabel laut, terutama untuk proses analisa gangguan, diharapkan informasi ini dapat memberikan pengetahuan yang lebih luas kepada seluruh masyarakat.

Pada penelitian ini penulis melakukan proses analisa gangguan melalui NMS (Network Monitoring System), kemudian berkoordinasi dengan tim Cable Landing Station Jakarta yang berada di Pluit untuk mengetahui penyebab kerusakan dan selanjutnya melakukan restorasi trafik ke jalur backup. Pada saat proses perbaikan 2 bulan setelah gangguan, penulis berada di cable landing station Jakarta untuk melakukan koordinasi dengan team Asean Cable Ship yang berada di kapal Asean Explorer dan tim cable landing station di Singapura. Dalam proses perbaikan, team Asean Cable Ship memberikan perintah kepada tim di cable landing station untuk melakukan pengetestan seperti elektroding tone, short circuit, open circuit.

\section{METODE PENELITIAN}

Metode penelitian yang digunakan dalam penelitian ini antara lain:

1. Studi Lapangan

Metode ini dilakukan dengan mengikuti, mengamati dan melakukan troubleshoot pada saat terjadi gangguan pada sistem komunikasi kabel laut Matrix Cable System sampai dengan proses perbaikan.

2. Wawancara

Dengan cara melakukan wawancara langsung dengan tim Network Operation Center yang berada di Cable Landing Station di Pluit, Network Operation Center di Kuningan dan Network Operation Center di Changi Singapura untuk memastikan proses yang berjalan dalam proses analisa sudah berjalan dengan benar.

3. Studi Literatur

Metode ini dilakukan untuk mendapatkan dasar teori yang akan menjadi pembanding seperti hasil redaman apakah masih masuk toleransi untuk pengiriman voice dan data.

\section{HASIL DAN PEMBAHASAN}

Sistem komunikasi kabel laut merupakan sistem komunikasi yang menggunakan media transmisi yang ditanam atau diletakkan di dasar laut untuk menghubungkan komunikasi antar pulau atau antar negara. Pada gambar 1, akan menunjukan sistem komunikasi kabel laut secara umum.

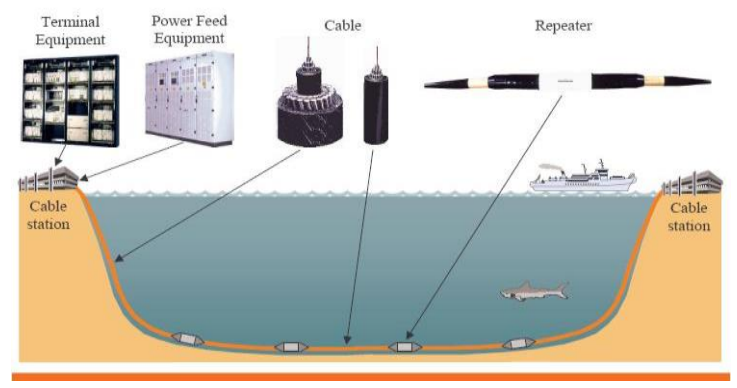

Gambar 1. Sistem Komunikasi Kabel Laut

Secara garis besar konfigurasi sistem komunikasi kabel laut dibagi menjadi dua perangkat utama yaitu :

1. Perangkat Bawah Laut (Wet Plant) terdiri dari :
a. Kabel Serat Optik
b. Cable Joint
c. Repeater
d. BU (Branching Unit)

2. Perangkat Terminal (Dry Plant) yang terdiri dari :
a. PFE (Power Feeding Equipment)
b. LTE (Line Terminating Equipment)
c. ME (Monitoring Equipment)

Sistem komunikasi kabel laut Matrix Cable System adalah jaringan kabel fiber optik bawah laut sepanjang $1055 \mathrm{~km}$ dari Singapura ke Jakarta yang dibangun oleh PT.Nap Info Lintas Nusa di Indonesia yang bekerja sama dengan Matrix Network Pte.Ltd di Singapura untuk menyediakan jaringan internasional dari Jakarta ke Singapura. Jaringan MCS mempunyai kapasitas bandwidth 60 Gbps dengan desain total kapasitas 5.12 Tbps dan mulai 
beroperasi sejak tanggal 8 Agustus 2008 . Pada gambar 2 akan menunjukan peta jaringan Matrix Cable System antara Jakarta, Indonesia ke Singapura.

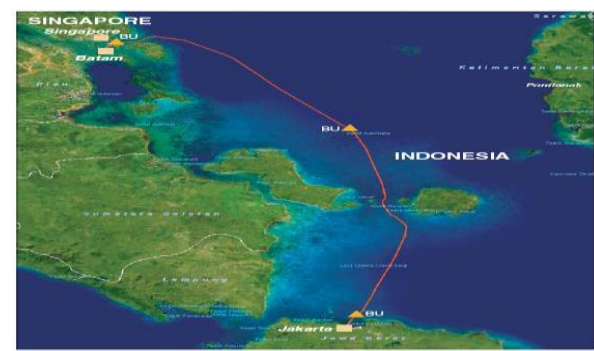

Gambar 2. Peta Jaringan Matrix Cable System

Sistem komunikasi kabel laut Matrix Cable System yang membentang dari Jakarta ke Singapura mempunyai beberapa segmen seperti yang akan ditujukan pada gambar 3, sehingga memudahman proses analisa apabila terjadi gangguan.

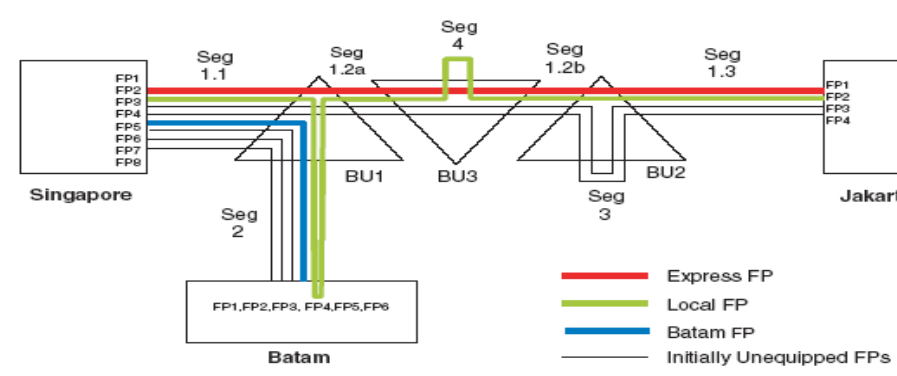

Gambar 3. Segmentasi Jaringan Matrix Cable System

Seperti yang terlihat pada gambar bahwa sistem komunikasi kabel laut Matrix Cable System mempunyai beberapa segmen jaringan, dan pada tabel 1 akan menunjukan lebih detail segmentasi jaringan pada sistem komunikasi kabel laut dari Jakarta sampai dengan Singapura.

Tabel 1. Daftar Segmen Jaringan Matrix Cable System

\begin{tabular}{|l|l|l|l|}
\hline Segment & $\begin{array}{c}\text { End } \\
\text { Point 1 }\end{array}$ & $\begin{array}{c}\text { End } \\
\text { Point 2 }\end{array}$ & $\begin{array}{l}\text { Approximate } \\
\text { Length (km) }\end{array}$ \\
\hline 1.1 & Singapura & BU 1 & 58.6 \\
\hline $1.2 \mathrm{a}$ & BU 1 & BU 3 & 96.7 \\
\hline $1.2 \mathrm{~b}$ & BU 3 & BU 2 & 861.0 \\
\hline 1.3 & BU 2 & Jakarta & 39.0 \\
\hline 2 & BU 1 & Batam & 5.7 \\
\hline
\end{tabular}

\begin{tabular}{|l|l|l|l|}
\hline Segment & $\begin{array}{c}\text { End } \\
\text { Point 1 }\end{array}$ & $\begin{array}{c}\text { End } \\
\text { Point 2 }\end{array}$ & $\begin{array}{c}\text { Approximate } \\
\text { Length }(\mathbf{k m})\end{array}$ \\
\hline 3 & BU 2 & Stub & 1.0 \\
\hline 4 & BU 3 & Stub & 1.0 \\
\hline
\end{tabular}

\section{Jenis Gangguan Pada MCS}

Setiap jaringan komunikasi mempunyai kerentanan terjadi gangguan tidak terkecuali untuk sistem komunikasi kabel laut. Pada sistem komukasi kabel laut Matrix Cable System juga beberapa kali mengalami gangguan dengan berbagai macam penyebab dalam saluran trasmisi. Gangguan yang pernah terjadi pada sistem komunikasi kabel laut Matrix Cable System antara lain gangguan pada elektrik dan shunt fault / fiber cut.

a. Gangguan Elektrik pada Matrix Cable System

Tegangan PFE (Power Feeding Equipment) yang fluktuatif menyebabkan performansi kabel laut menjadi terganggu karena aliran daya yang diberikan pada perangkatperangkat amplifier yang berada di laut menjadi tidak stabil. Gangguan elektrik bisa terjadi karena adanya arus bawah laut yang sangan kuat sehingga membuat kabel laut bergerak ataupun adanya gangguan pada PFE itu sendiri. Pada sistem komunikasi kabel laut Matrix Cable System, termonitor sempat beberapa kali mengalami gangguan tegangan PFE. Pada gambar 4 dan 5 akan menunjukan fluktuasi tegangan di PFE Singapura dan Jakarta yang terlihat melalui TEMS sehingga mengakibatkan jaringan Matrix Cable System mengalami gangguan dalam beberapa menit. 


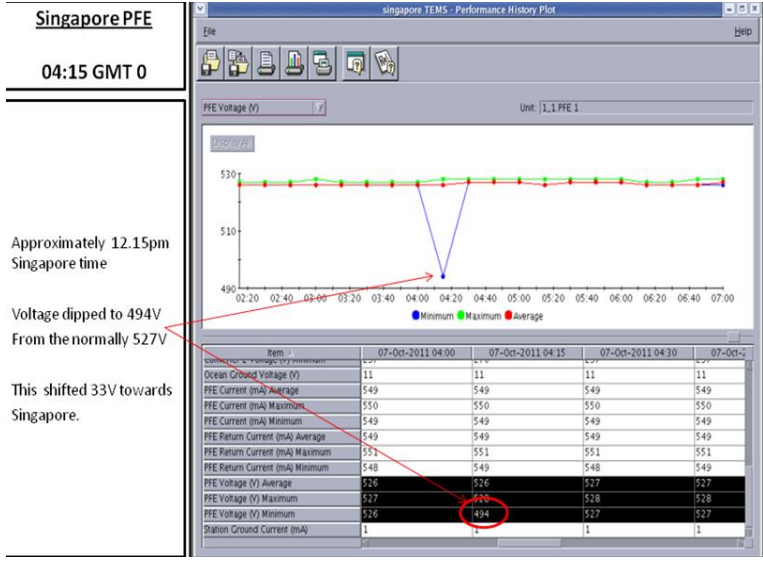

Gambar 4. Fluktuasi Tegangan PFE Singapura

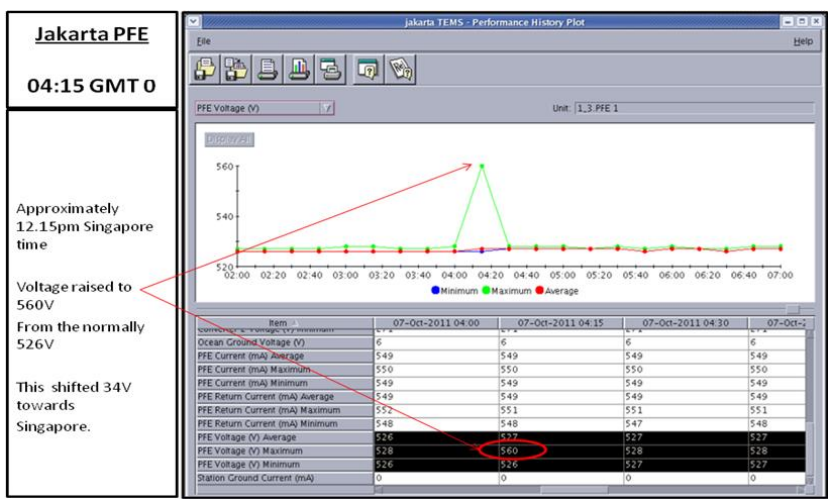

Gambar 5. Fluktuasi Tegangan PFE Jakarta

Dari gambar 4 terlihat bahwa tegangan PFE dari monitoring TEMS yang berada di Singapura mengalami penurunan tegangan pada jam 04.15 GMT, sedangkan pada gambar 5 menunjukan kenaikan tegangan pada PFE pada pukul 04.15 GMT. Hal tersebut terjadi karena pada jangka waktu tersebut terjadi arus bawah laut yang kuat sehingga mengakibatkan kabel yang berada dipermukaan laut bergoyang dan komunikasi terganggu.

\section{b. Fiber Cut}

Fiber cut pada jaringan sistem komunikasi kabel laut bisa terjadi karena beberapa hal, seperti terkena jangkar kapal laut atau terjadi pencurian kabel. Untuk menentukan lokasi shunt fault atau fiber cut dapat menggunakan perbandingan PFE antara dua stasiun dengan melakukan pengukuran tahanan dan kapasistansi. Pada tugas akhir ini, akan membahas mengenai gangguan pada sistem komunikasi kabel laut yang disebabkan oleh fiber cut di tengah laut karena terkena jangkar kapal.

\section{Pengananan Gangguan Pada MCS}

Sistem komukasi kabel laut suatu saat pasti akan terjadi gangguan dan itu tidak dapat dihindari karena seperti yang disebutkan sebelumnya bahwa gangguan dapat disebabkan oleh banyak faktor. Oleh karena itu, apabila suatu saat terjadi gangguan maka diperlukan penanganan yang cepat sehingga proses komukasi juga cepat kembali normal. Untuk proses perbaikan sistem komunikasi kabel laut, memang membutuhkan waktu yang lama karena adanya perizinan yang harus dipenuhi dikarenakan kabel laut menghubungkan beberapa negara dan proses perizinan disetiap negara pasti berbeda.

Pada gambar 6 akan menunjukan flow chart langkah-langkah penanganan gangguan sistem komunikasi kabel laut dari mulai persiapan perbaikan kabel, pengukuran lokasi gangguan, penyambungan sampai dengan pengujian selesai.

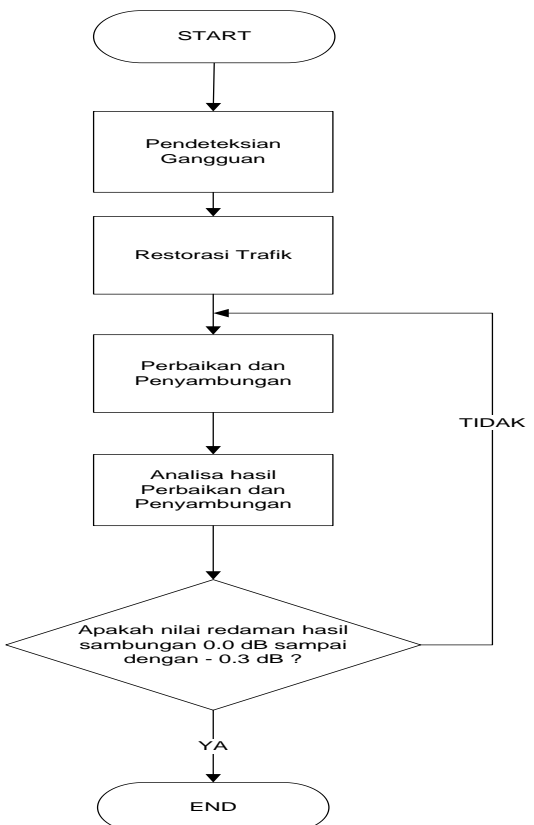

Gambar 6. Flow chart Penanganan
Gangguan 
Gangguan Transmisi Pada Sistem Komunikasi Kabel Laut Matrix Cable System

Pada 4 agustus 2012 Matrix Cable System mengalami gangguan transmisi yang yang mengakibatkan seluruh layanan yang disewakan seperti IPLC (International Private Leased Circuit) dan IP Transit down. IPLC merupakan layanan bagi pelanggan yang membutuhkan koneksi ke Singapura untuk mengakses perangkatnya karena pelanggan tersebut mempunyai perangkat di Singapura tetapi tidak mempunyai jalur Jakarta ke Singapura. Sedangkan IP Transit adalah layanan disewakan kepada ISP (Internet Service Provider) seperti SmartFren, Axis, Hutchinson, Biznet, First Media yang membutuhkan interkoneksi trafik ke global internet (bandwidth internet internasional) sehingga pengguna internet dapat mengakses konten-konten yang servernya berada di luar Indonesia.

Setelah diketahui adanya gangguan pada sistem komunikasi kabel laut MCS (Matrix Cable System) maka proses selanjutnya adalah menganalisa gangguan yang terjadi, kemudian me-restorasi trafik dan melakukan proses perbaikan kabel laut itu sendiri seperti yang ditujukan pada gambar 6 mengenai flow chart penanganan gangguan. Untuk proses-proses tersebut akan dijelaskan dan dianalisa pada bab selanjutnya.

\section{Pendeteksiaan Gangguan dan Perbaikan Pada Fiber Optik}

Pendeteksian gangguan pada sistem komunikasi kabel laut MCS (Matrix Cable System) mengandalkan NMS(Network Monitoring System) berupa TEMS (Tyco Element Management System) dan NMS Whatsup Gold untuk memonitor jaringan IP Transit dan internet. TEMS juga dilakukan untuk proses troubleshoot gangguan dengan melakukan pengetesan HLLB (High-Loss Loppback) dan pengetesan fiber pair dari Jakarta Singapura untuk mengetahui titik putus.

\section{Deteksi Gangguan Melalui Network Monitoring System}

Pendeteksian gangguan yang terjadi pada sistem komunikasi kabel laut MCS (Matrix Cable System) berupa notifikasi alarm yang berbunyi dan tampilan yang berubah merah di NMS MCS (Matrix Cable System) backbone yang berada Plaza Kuningan. Pada NMS seperti pada gambar 7 terdeteksi bahwa koneksi ke Internet Exchange di Equinix dan SOX di Singapura serta koneksi ke HKIX (Hongkong Internet Exhange) down.

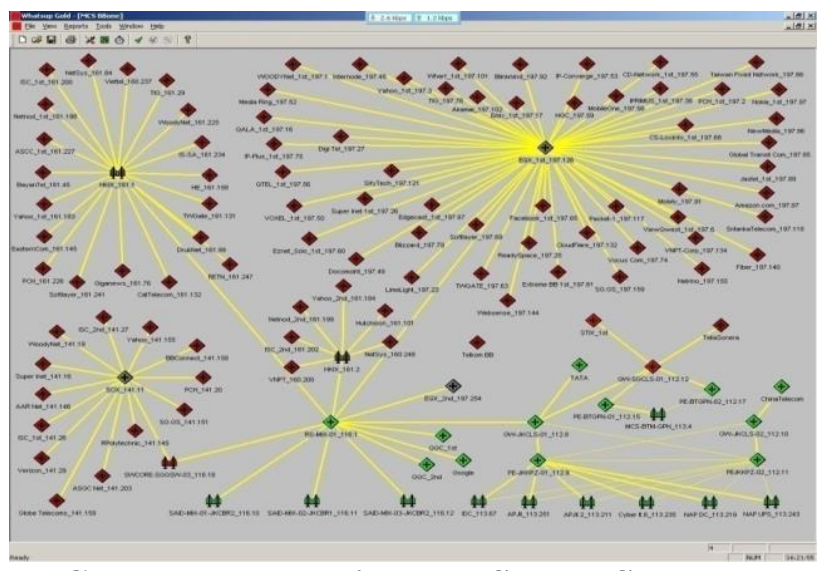

Gambar 7. Tampilan NMS Pada Saat Jaringan MCS Down

Setelah mendapatkan notifikasi alarm, maka administrator jaringan menindak lanjuti dengan melakukan koordinasi bersama dengan tim di cable landing station Jakarta dan Singapura. Koordinasi tersebut dilakukan untuk memastikan interkoneksi dari Jakarta ke Singapura karena notifikasi dari NMS (Network Monitoring System) menunjukan bahwa jaringan yang menuju ke Singapura seluruhnya down.

\section{Restorasi Trafik}

Restorasi trafik adalah proses untuk memulihkan trafik yang ada ke jalur yang lain. Restorasi trafik dibutuhkan untuk memindahkan trafik yang ada ke jalur proteksi atau jalur backup sehingga trafik 
dapat berjalan meskipun jalur utama sedang bermasalah. Pada saat terjadi gangguan seperti fiber cut yang membutuhkan waktu cukup lama untuk proses perbaikannya, maka harus dilakukan restorasi trafik secepatnya untuk mem-backup transportasi data yang sedang berlangsung. Proses perbaikan kabel laut sendiri membutuhkan waktu yang lama karena sistem komunikasi kabel laut menghubungkan beberapa negara sehingga diperlukan mengurus perizinan di negara tersebut.

Pada saat restorasi trafik, PT.NAP Info Lintas Nusa dan Matrix Network bekerja sama dengan Pgascom untuk menyediakan jalur restorasi dari Jakarta ke Batam. Pada gambar 8 akan menunjukan jalur restorasi jaringan MCS pada saat terjadi gangguan.

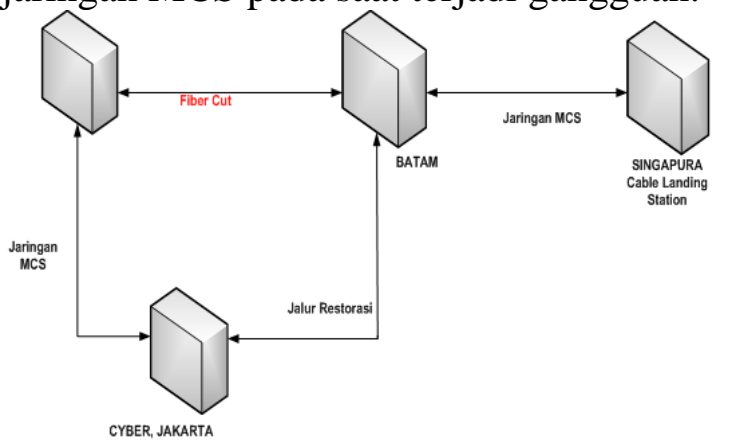

Gambar 8. Jalur Restorasi MCS

\section{Deteksi Kerusakan}

Pendeteksian kerusakan dilakukan untuk mencari titik permasalahan sehingga mengetahui langkah selanjutnya yang akan dilakukan. Pendeteksian dilakukan dengan melakukan pengetesan HLLB (High-Loss Loppback) dan TEMS (Tyco Element Management System) Line Monitoring System ke semua fiber pair 1, 2, 3 dan 4 yang terhubung langsung dari Jakarta ke Singapura.

\section{Pengetesan HLLB}

Proses pengetesan HLLB (High-Loss Loppback) dilakukan untuk mengetahui titik span loss pada setiap repeater. Sistem komunikasi kabel laut MCS (Matrix Cable System) mempunyai 9 repeater untuk jarak $1055 \mathrm{Km}$. Sebagai acuan dalam pengukuran HLLB (High-Loss Loppback), pada gambar 9 akan menunjukan hasil pengetasan HLLB (High-Loss Loppback) dalam kondisi normal.

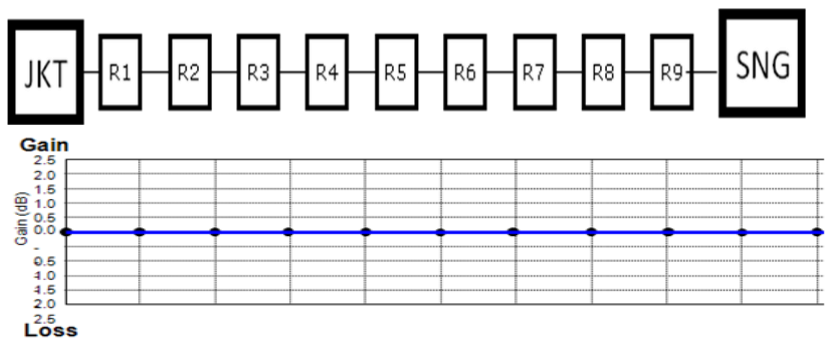

\section{Gambar 9. Hasil Test HLLB dalam Kondisi Normal}

Pengetesan HLLB (High-Loss Loppback), harus dilakukan sesuai dengan prosedur yang ada, berikut langkah-langkah dalam pengetesan HLLB;

a. Melakukan pengetesan HLLB dengan menggunakan TEMS (Tyco Element Management System).

b. Pada LME (Line Monitoring Equipment) TEMS, melihat status meansurement untuk memastikan dalam kondisi idle.

c. Melakukan pengetesan HLLB dengan memilih LME untuk pengetesan dan klik kanan, lalu klik start HLLB measurenment.

d. Memilih frekuensi untuk melakukan pengetesan Low Frequency : 191.700 Tera hertz atau High frequency : 195.050 Tera hertz.

e. Setelah itu start HLLB measurement.

f. Setelah dilakukan pengetesan sesuai dengan langkah-langkah diatas, pada gambar 10, 11, 12, dan 13 akan menunjukan hasil pengetesan HLLB pada fiber pair 1 sampai dengan fiber pair 4 disisi Jakarta. 


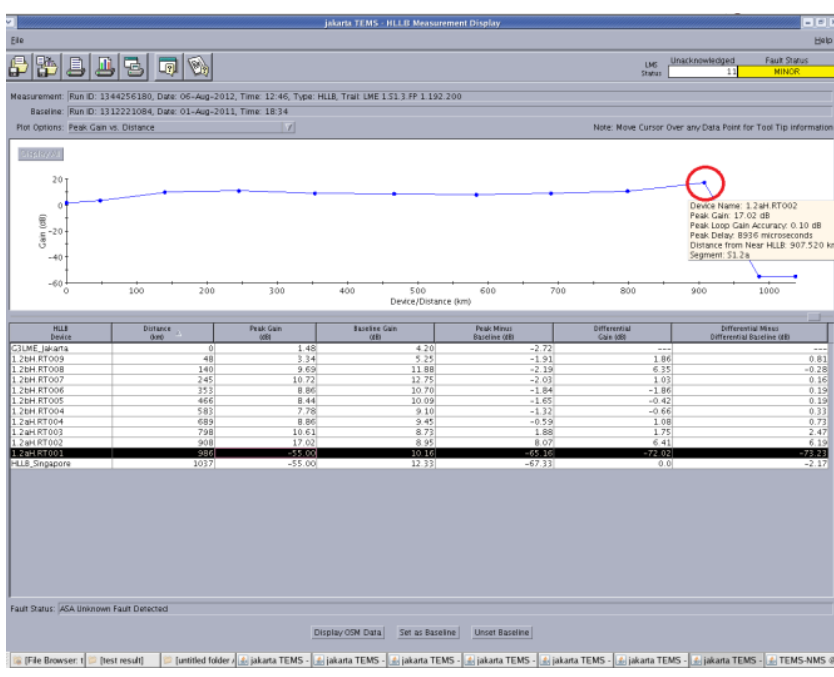

Gambar 10. Hasil Test HLLB FP 1

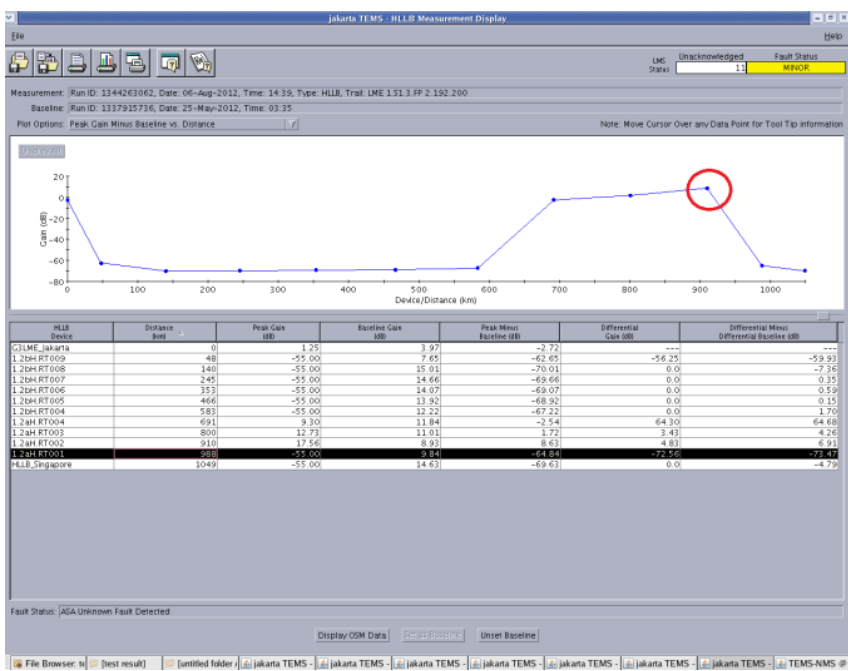

Gambar 11 Hasil Test HLLB FP 2

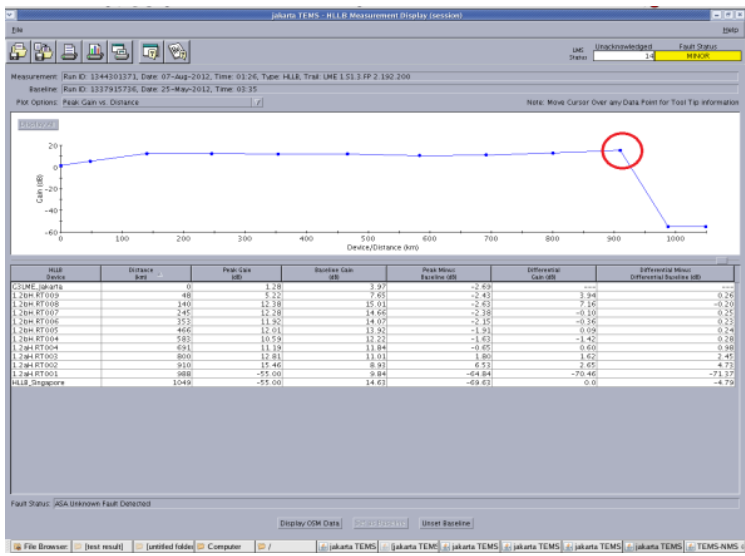

Gambar 12. Hasil Test HLLB FP 3

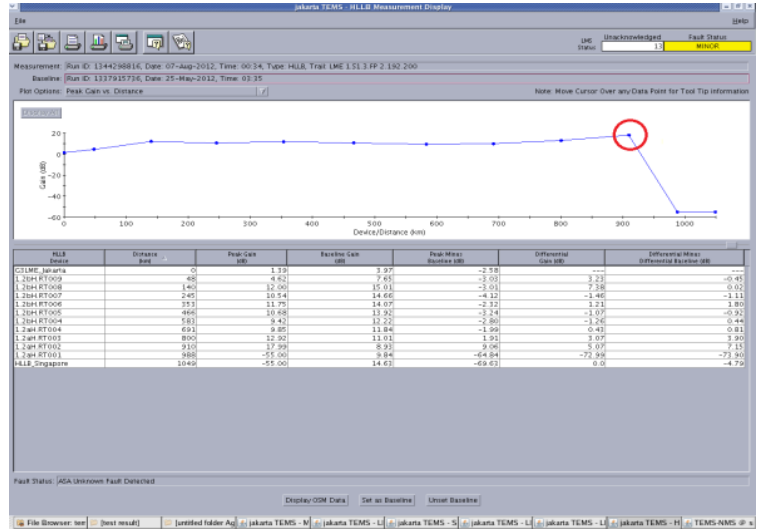

Gambar 13. Hasil Test HLLB FP 4

Dari hasil pengetesan HLLB (High-Loss Loppback) pada gambar 10 sampai 13 terlihat bahwa terjadi penurunan gain pada repeater 9 (1.2 aH RT001). Repeater tersebut berada pada segmen 1.2A. Dengan hasil tersebut dapat diindikasikan bahwa terjadi kerusakan di segmen 1.2A. Untuk mengetahui titik pasti kerusakan harus dilakukan pengecekan lebih lanjut dengan menelusuri kabel laut pada segment tersebut.

Pengetesan dengan TEMS (Tyco Element Management Systems)

Pengetesan menggunakan TEMS LMS (Line Monitoring System) dilakukan untuk mengetahui letak atau lokasi terjadinya fiber cut. Pengetesan dilakukan diseluruh fiber pair yang terhubung langsung dari Jakarta - Singapura dan hasilnya ditujukan pada gambar 14 sampai 17 berikut:

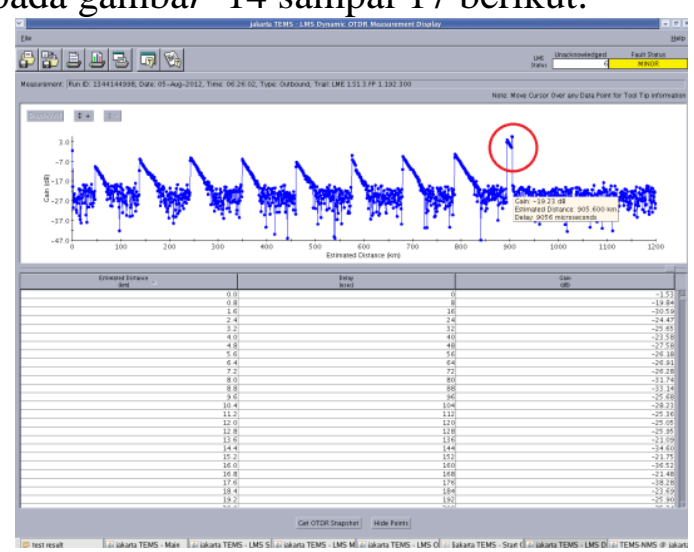

Gambar 14. Pengetesan TEMS di FP 1 Jakarta 


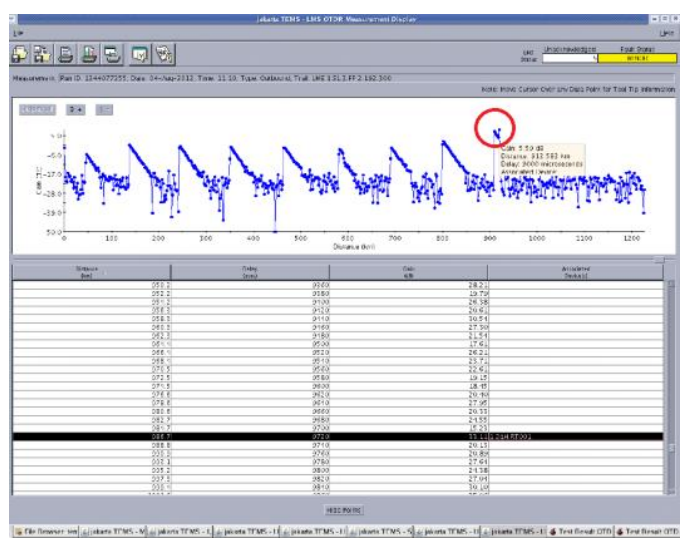

Gambar 15. Pengetesan TEMS di FP 2 Jakarta

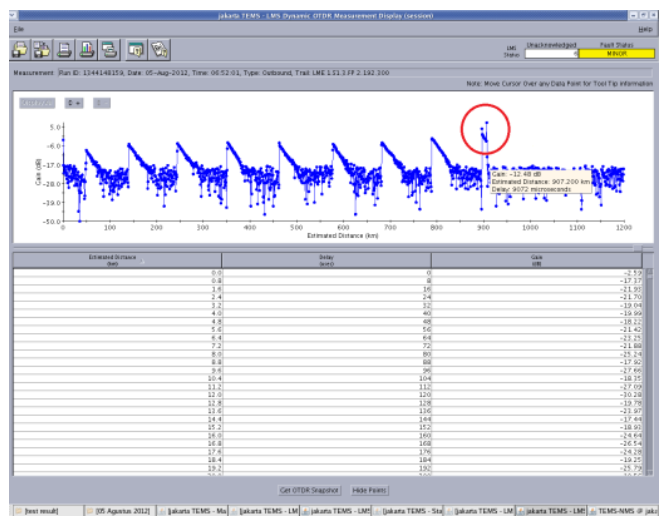

Gambar 16. Pengetesan TEMS di FP 3 Jakarta

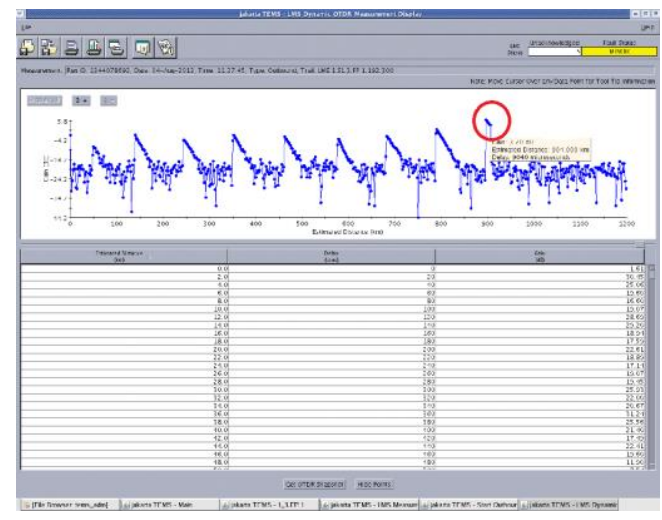

Gambar 17. Pengetesan TEMS di FP 4 Jakarta

Dari hasil pengetesan melalui TEMS (Tyco Element Management System) diketahui bahwa disemua fiber pair mengalami degradasi sinyal atau loss sinyal setelah jarak $900 \mathrm{Km}$ dari Jakarta, dengan total panjang kabel dari Jakarta ke Singapura yaitu $1055 \mathrm{~km}$. Dari hasil pengetesan pada fiber pair 1, 2, 3 dan 4 melalui TEMS, maka dapat diambil kesimpulan sebagai berikut:

1. Hasil pengetesan dari semua fiber pair menunjukkan lokasi terjadinya degradasi sinyal pada jarak $900 \mathrm{Km}$ dari Jakarta cable landing station, yang dapat diartikan $(1055 \mathrm{Km}-900 \mathrm{Km})=$ $155 \mathrm{Km}$ dari Singapura cable landing station ke arah Jakarta.

2. Apabila melihat dari segmentasi jaringanMatrix Cable Sytem bahwa jarak setelah $900 \mathrm{Km}$ berada pada segmen 1.2A yang terletak dari brancing unit 1 ke arah brancing unit 3 .

\section{Perbaikan dan Penyambungan}

Setelah titik lokasi gangguan diketahui, maka akan dilakukan perbaikan kabel. Untuk perbaikan kabel, Matrix dan NAP Info bekerja sama dengan ASEAN Explorer serta ASEAN Cable Ship untuk melakukan penyambungan kabel fiber optik bawah laut pada segmen 1.2A. Perbaikan bertujuan untuk mengembalikan performansi sistem menjadi normal kembali, setelah lokasi gangguan diketahui dengan melakukan pengetesan HLLB (High-Loss Loppback) dan OTDR (Optical Time Domain Reflector) measurement menggunakan LME (Line Monitoring Equipment). Untuk tahapan perbaikan dilakukan, maka harus dilakukan proses power down PFE (Power Feeding Equipment) sehingga proses perbaikan berlangsung aman karena tidak ada tegangan yang mengalir. Langkah-langkah perbaikan dan penyambungan sistem komunikasi kabel laut Matrix Cable System, sebagai berikut:

1. ASEAN Explorer akan melakukan penelusuran kabel sepanjang segment 1.2a dengan mendeteksi electroding tone. Penelusuran kabel dilakukan menggunakan sebuah robot yang sering disebut ROV, tampilan ROV seperti pada Gambar 18. 

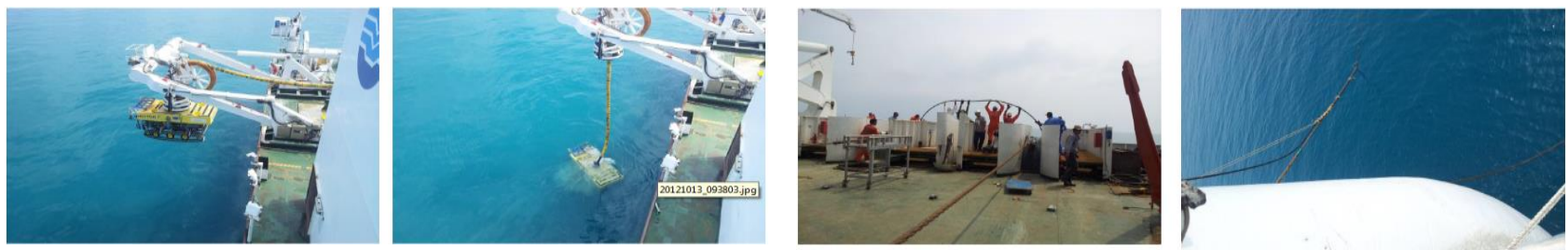

Gambar 18. Robot ROV

Berdasarkan hasil pengetesan elektroding dan penelusuran kabel sepanjang segmen 1.2A yang dilakukan oleh ROV, diketahui bahwa terjadi 2 fiber cut. Letak terputusnya kabel berada di titik $1.9 \mathrm{Km}$ dan $2.36 \mathrm{Km}$ ke arah Singapura dari JB (Joint Box) 2.2.

2. Setelah diketahui titik kerusakan, kabel dibawa ke atas kapal untuk dilakukan perbaikan dengan melakukan penyambungan dikabel yang mengalami kerusakan. Penyambungan kabel fiber optik dilakukan dengan menggunakan fusion splicer. Pada gambar 19 akan menunjukan beberapa proses penyambungan kabel fiber optik.
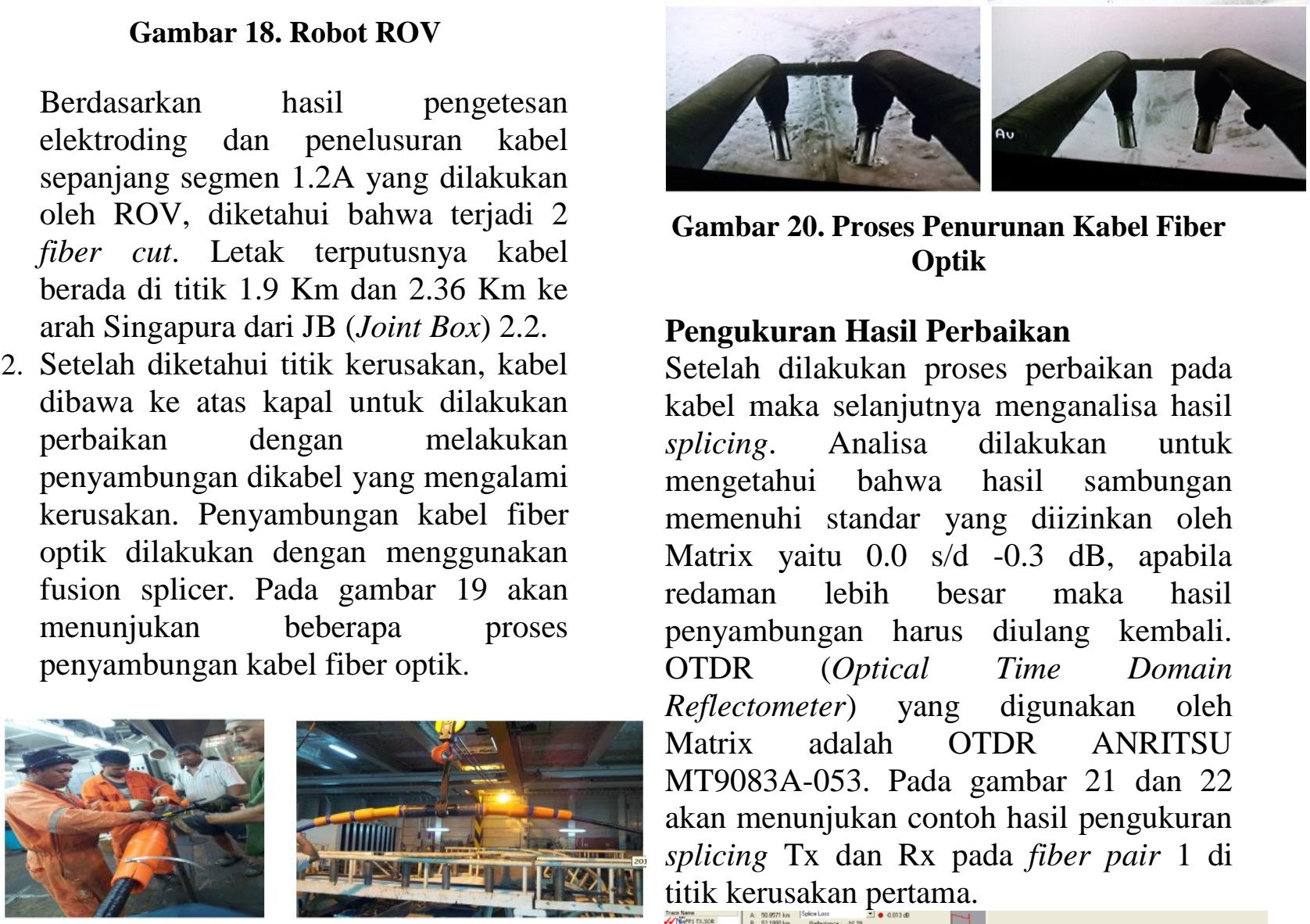

Gambar 20. Proses Penurunan Kabel Fiber Optik

\section{Pengukuran Hasil Perbaikan}

Setelah dilakukan proses perbaikan pada kabel maka selanjutnya menganalisa hasil splicing. Analisa dilakukan untuk mengetahui bahwa hasil sambungan memenuhi standar yang diizinkan oleh Matrix yaitu $0.0 \quad \mathrm{~s} / \mathrm{d} \quad-0.3 \mathrm{~dB}$, apabila redaman lebih besar maka hasil penyambungan harus diulang kembali. OTDR (Optical Time Domain Reflectometer) yang digunakan oleh Matrix adalah OTDR ANRITSU MT9083A-053. Pada gambar 21 dan 22 akan menunjukan contoh hasil pengukuran splicing Tx dan Rx pada fiber pair 1 di titik kerusakan pertama.

Gambar 19. Proses Penyambungan Kabel Fiber Optik

3. Jika proses penyambungan selesai, maka selanjutnya melakukan pengukuran hasil sambungan disetiap serat optik untuk mengetahui redaman yang dihasilkan dari penyambungan. Standard redaman dari Matrix yang diperbolehkan yaitu $0.0 \mathrm{~dB}$ sampai -0.3 $\mathrm{dB}$. Jika proses pengukuran dan analisa selesai maka kabel fiber optik akan kembali diturukan kelautan. Pada gambar 20 akan menunjukan proses penurunan kabel fiber optik ke laut.

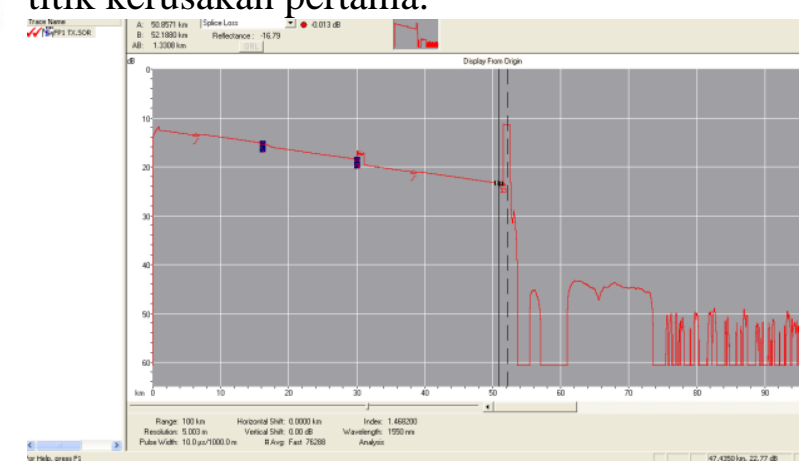

Gambar 21. Pengukuran Hasil Splicing FP 1 Tx di titik Kerusakan Pertama 


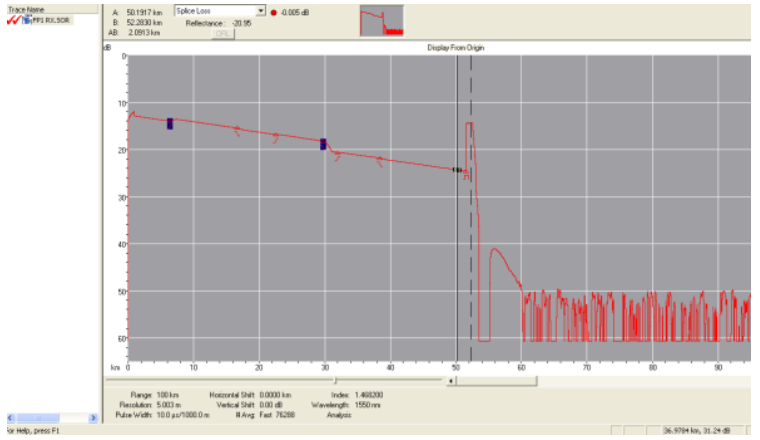

Gambar 22. Pengukuran Hasil Splicing FP 1 Rx di titik Kerusakan Pertama

Dari hasil pengukuran melalui OTDR pada fiber pair 1 di titik kerusakan pertama terlihat bahwa nilai redaman untuk transmit $-0.013 \mathrm{~dB}$ dan receive $-0.005 \mathrm{~dB}$. Nilai tersebut sudah memenuhi standart redaman yang diizinkan oleh Matrix, yaitu berkisar $0.0 \mathrm{~dB}-0.3 \mathrm{~dB}$. Untuk data selengkapnya mengenai hasil pengukuran setelah hasil penyambungan di titik kerusakan pertama dan kedua, akan dibuat tabel dan hasilnya ditunjukan pada tabel 2 di bawah ini.

Tabel 2. Hasil Pengukuran Serat Optik Setelah Penyambungan

\begin{tabular}{|c|c|c|}
\hline $\begin{array}{c}\text { Fiber } \\
\text { pair }\end{array}$ & $\begin{array}{c}\text { OTDR Test Result } \\
\text { 1st Splice }\end{array}$ & $\begin{array}{c}\text { OTDR Test Result } \\
\text { 2nd Splice }\end{array}$ \\
\cline { 2 - 3 } & Spice Loss(dB) & Spice Loss(dB) \\
\hline FP1 Tx & -0.013 & -0.220 \\
\hline $\begin{array}{c}\text { FP1 } \\
\text { Rx }\end{array}$ & -0.005 & -0.066 \\
\hline FP2 Tx & -0.009 & -0.181 \\
\hline $\begin{array}{c}\text { FP2 } \\
\text { Rx }\end{array}$ & -0.021 & -0.056 \\
\hline FP3 Tx & -0.015 & -0.063 \\
\hline $\begin{array}{c}\text { FP3 } \\
\text { Rx }\end{array}$ & -0.007 & -0.011 \\
\hline FP4 Tx & -0.009 & -0.116 \\
\hline $\begin{array}{c}\text { FP4 } \\
\text { Rx }\end{array}$ & -0.015 & -0.086 \\
\hline
\end{tabular}

Dari hasil analisa diatas menunjukkan bahwa penyambungan berhasil dengan baik, karena besar splice loss masih dalam standard yang diizinkan oleh Matrix yaitu $0.0-0.3 \mathrm{~dB}$. Setelah hasil splicing dianalisa dan kabel sudah diletakkan kembalikan dilautan selanjutnya team dari
CLS (cable landing station) Singapura kembali melakukan pengetesan HLLB (High-Loss Loppback) dari Singapura ke Jakarta. Dari hasil pengetesan tersebut terlihat tidak terjadi degradasi sinyal sepanjang jalur kabel fiber optik Jakarta ke Singapura. Pengetesan HLLB dilakukan setelah PFE dinormalkan kembali. Pada gambar 23 - 26 berikut:

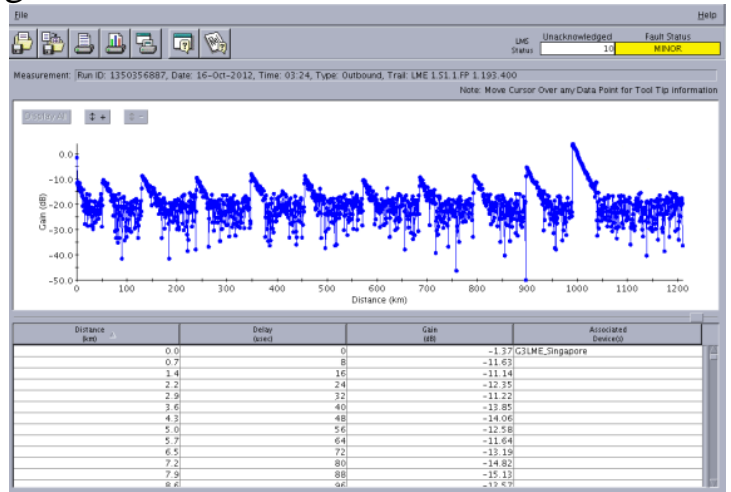

Gambar 23. Pengetesan HLLB di FP 1 dari Singapura Setelah Perbaikan

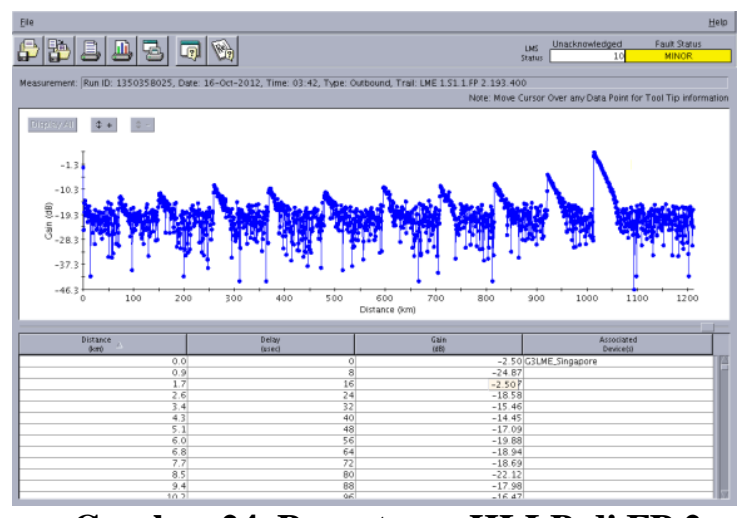

Gambar 24. Pengetesan HLLB di FP 2 dari Singapura Setelah Perbaikan

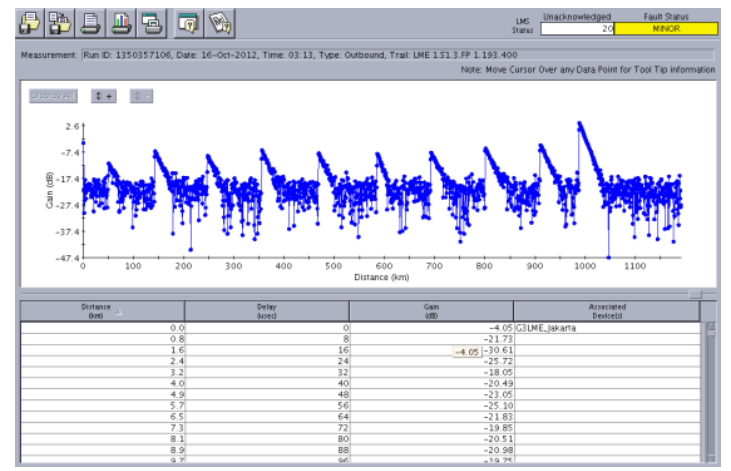

Gambar 25. Pengetesan HLLB di FP 3 dari Singapura Setelah Perbaikan 


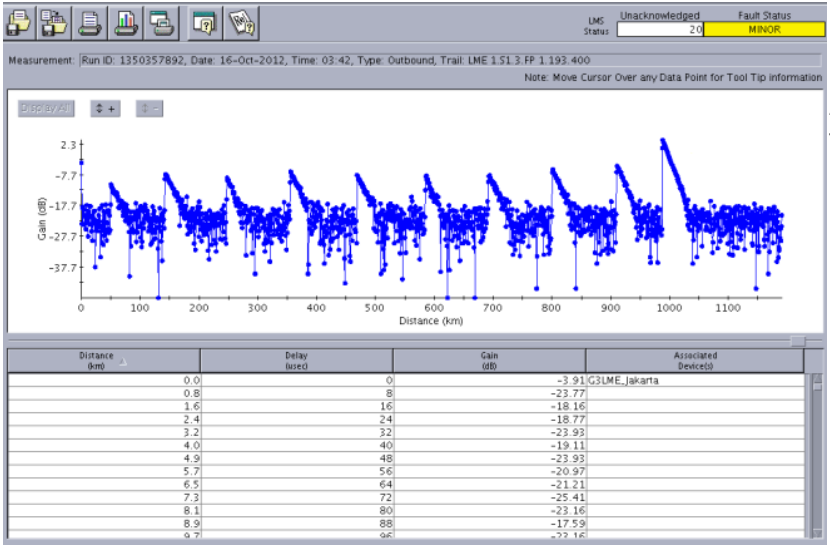

Gambar 26. Pengetesan HLLB di FP 4dari Singapura Setelah Perbaikan

\section{Analisis Implementasi dan Perbaikan Fiber Optik}

Dari hasil restorasi, pengukuran sampai dengan perbaikan pada gangguan jaringan sistem komunikasi kabel laut Matrix Cable System, maka dapat diambil beberapa analisa sebagai berikut;

1. Waktu restorasi trafik memerlukan waktu 12 jam, disebabkan oleh belum adanya backup permanen karena biaya untuk mengadakan backup permanen tinggi. Sehingga pada saat terjadi gangguan harus menyewa terlebih dahulu. Setelah kejadian tersebut, maka mulai tahun ini sudah ada kemajuan dengan menyewa jaringan backup ke provider telekomunikasi nasional. Sedangkan untuk proses restorasi trafik kabel darat MCS (Matrix Cable System) hanya membutuhkan waktu $50 \mathrm{~ms}$ karena menggunakan teknologi Metro Ethernet bertopologi ring yang sudah auto backup.

2. Proses perbaikan kabel laut Matrix Cable System membutuhkan waktu yang lama, karena harus memproses izin dari kementerian terkait di Indonesia dan Singapura. Seperti di Indonesia membutuhkan izin dari Kementerian Pertahanan, Kementerian Perikanan dan Kelautan, Kementerian Dalam Negeri, Kementerian Luar Negeri, TNI/Polri. Sedangkan jika perbaikan kabel darat MCS tidak membutuhkan perizinan tersebut sehingga proses perbaikan lebih cepat.

3. Setelah dilakukan perbaikan, terlihat bahwa hasil pengukuran dari hasil sambungan setiap serat optik berkisar antara $-0.005 \mathrm{~dB}$ sampai dengan -0.220 $d B$, sehingga sudah memenuhi standard yang ditentukan oleh Matrix. Hasil sambungan dinyatakan gagal dan harus diulang kembali, jika splice loss tidak memenuhi standard yang ditentukan yaitu lebih besar dari $0.0 \mathrm{~dB}$ sampai dengan - $0.3 \mathrm{~dB}$.

\section{SIMPULAN}

Dari implemetasi dan pengujian serta hasil analisa gangguan sistem transmisi komunikasi kabel laut MCS (Matrix Cable System), maka diambil kesimpulan sebagai berikut :

1. Pada saat proses restorasi trafik yang dilakukan setelah diketahui adanya gangguan transmisi yang disebabkan oleh fiber cut, sistem komunikasi kabel laut MCS (Matrix Cable System) belum memiliki backup permanen dikarenakan biaya yang tinggi, sehingg proses restorasi trafik membutuhkan waktu yang lama. Karena pentingnya backup permanen dalam penanggangan restorasi, maka mulai tahun 2012 sistem komunikasi kabel laut MCS (Matrix Cable System) sudah menyewanya ke provider lain.

2. Proses perbaikan membutuhkan waktu lama, karena harus memproses perizinan di kedua negara yaitu Indonesia dan Singapura.

3. Hasil pengukuran redaman (splice loss) dari hasil sambungan setiap serat optik berkisar antara $-0.005 \mathrm{~dB}$ sampai dengan $-0,220 \mathrm{~dB}$. Hasil tersebut menunjukan bahwa hasil sambungan sudah memenuhi standar yang ditentukan oleh Matrix yaitu tidak lebih besar dari $0.0-0.3 \mathrm{~dB}$. 


\section{DAFTAR PUSTAKA}

[1] Crisp, John dan Elliot, Barry. Serat Optik : Sebuah Pengantar. Edisi 3. Jakarta : Penerbit Erlangga. 2008.

[2] Rapp. Ronald J., Dr. The 34thAnnual COLP Conference, Submarine Cables: Critical Infrastructure Supplier Perspective. Tyco Electronics Subsea Communications LLC (TE SubCom). 2010.

[3] Telecommunication (US) Inc, Tyco. Matrix Cable System Manual. USA: Tyco Telecommunication. 2008.

[4] Telecommunication (US) Inc, Tyco. Matrix Cable System Operation and Maintenance. USA: Tyco Telecommunication. 2008.

[5] Telecommunication (US) Inc, Tyco. Tyco Element Management System (TEMS) User's Manual For Matrix Cable System. USA: Tyco Telecommunication. 2008.

[6] Yanthony, Darius. Analisis Perbandingan dan Kinerja Sistem Komunikasi Kabel Laut SEA-ME-WE 3 dan 4. Skripsi. Universitas Indonesia. Depok. 2009.

[7] Kurniawan, Dody, Tearalangi, Teha dan Y, Dwi, Pratomo. Perencanaan Sistem Komunikasi Kabel Laut Link Sangatta (Kalimantan) - Towale (Sulawesi). Tugas Akhir. Universitas Telkom. Bandung. 2007. 